\title{
Gaining body temperature in horses: mercury, digital and infrared thermometer in different locations
}

\author{
Aferição da temperatura corporal em equinos: \\ avaliações de diferentes métodos e locais
}

\begin{abstract}
Ana Paula da Costa Rodrigues ${ }^{1 *}$ (10), Eduarda Sacardi Severo ${ }^{(1 D}$, Geórgia Camargo Góss ${ }^{2}$ (D), Gabriela Döwich $^{1}$ (D), Onildo Gonçalves Nunes Junior ${ }^{1}$ (D), Renato Duarte Icart ${ }^{3}$ (D), Marcos da Silva Azevedo ${ }^{1}$ (i)
\end{abstract}

\begin{abstract}
The physical examination has several stages, one of which is the measurement of body temperature, when it exceeds the physiological values is indicative of some disease or hyperthermia, for this in veterinary medicine the mercury or digital thermometer is commonly used. The objective of this work is to compare if there is a difference between the mercury thermometer and the infrared thermometer or digital thermometer, as well as to identify if there is a difference between the measurement locations with the infrared thermometer and the mercury column thermometer and digital thermometer. Infrared temperature was evaluated in three places: oral mucosa, pinna and anal or vaginal mucosa (females), then a digital thermometer, followed by mercury, which was used as a reference standard. There was a statistical difference between the mercury thermometer and the infrared thermometer, when measured on the anal or vaginal mucosa and on the oral mucosa. The infrared thermometer, in the ear, and the digital thermometer did not differ from the mercury thermometer, demonstrating that these present similar values during the temperature measurement. The infrared thermometer proved to be little invasive and fast when compared to the others. However, some limitations were observed in the measurement of body temperature with the infrared thermometer measured in the ear. It is concluded that the infrared thermometer, used in the ear, and the digital thermometer are equivalent to the mercury thermometer and can be used in horses, however, more studies on this topic are still needed.
\end{abstract}

KEYWORDS: thermometer; horses; infra-red.

RESUMO: O exame físico tem várias etapas, uma delas é a aferição da temperatura corporal, quando ultrapassa os valores fisiológicos é indicativo de alguma enfermidade ou hipertermia, para isso na medicina veterinária é comumente utilizado o termômetro de mercúrio ou o digital. O objetivo desse trabalho é comparar se existe diferença entre o termômetro de mercúrio e o termômetro infravermelho ou termômetro digital, bem como identificar se existe diferença entre os locais de aferição com o termômetro infravermelho e o termômetro de coluna de mercúrio e termômetro digital. Realizava-se a avaliação da temperatura com o infravermelho, em três lugares: mucosa oral, pavilhão auricular e mucosa anal ou vaginal (fêmeas), depois termômetro digital, seguido pelo de mercúrio que foi utilizado como padrão de referência. Observou-se diferença estatística entre o termômetro de mercúrio e o termômetro infravermelho, quando aferido na mucosa anal ou vaginal e na mucosa bucal. Já o termômetro infravermelho, no pavilhão auricular, e o digital não diferiram do termômetro de mercúrio, demonstrando que estes apresentam valores semelhantes durante a aferição de temperatura. $\mathrm{O}$ termômetro infravermelho se demonstrou pouco invasivo e rápido quando comparados aos demais. Entretanto foram observadas algumas limitaçôes da mensuração da temperatura corporal com o termômetro infravermelho aferido no pavilhão auricular. Conclui-se que o termômetro infravermelho, utilizado no pavilhão auricular, e o termômetro digital se equivalem ao termômetro de mercúrio e podem ser utilizados em equinos, porém ainda é preciso mais estudos sobre esse tema.

PALAVRAS-CHAVE: termômetro; cavalos; infravermelho.

\section{INTRODUCTION}

The measurement of body temperature is an important step in the physical examination of the patient. In addition to being a low-invasive method, when it exceeds physiological values, it may be indicative of some infectious process. Since the rise in body temperature is one of the main clinical signs present in infectious processes. However, hyperthermia can occur when there is an increase in temperature without being

'Universidade Federal do Pampa, campus Uruguaiana - Uruguaiana (RS), Brazil.

${ }^{2}$ Centro Universitário Instituto Educacional do Alto Uruguai.

${ }^{3}$ Médico Veterinário.

*Corresponding author: anapaulacrodrigues@hotmail.com

Received: 09/23/2020. Accepted: 11/16/2020 
of inflammatory origin, such as dehydration, exercise and high ambient temperature (FEITOZA, 2014).

Horses, like other domestic species, maintain their body temperature within certain limits, even with variations in environmental conditions (REED; BAYLY; SELLON, 2017). In equine species, normal body temperature can vary between 37.2 to $38.2^{\circ} \mathrm{C}$ (CUNNINGHAM, 1999).

In animals, the rectal mucosa is the most reliable and most accurate place to obtain body temperature (GREER et al., 2007). The measurement of rectal temperature in horses can generate discomfort, and the manifestation of unwanted reactions on the part of the animal may occur, putting the professional and the animal at risk (FRADEN, 1991; KUNKLE; NICKLIN; SULLIVAN-TAMBOE, 2004).

For measuring the temperature, mercury and digital thermometers are commonly used (MACKOWIAK, 2005). The mercury thermometer, considered the standard for measuring the temperature, has the disadvantage of being able to break inside the rectal mucosa when the animal makes an abrupt movement, whereas the digital thermometer has as its main disadvantage an incorrect temperature measurement when not properly inserted and not maintaining contact of the bulb with the rectal mucosa (FEITOZA, 2014).

Currently, another method of temperature evaluation that has been used frequently in humans and small animals is the method that uses infrared radiation, a resource that has been proving to be highly efficient (BRIOSCHI; MACEDO; MACEDO, 2003), and in humans this type of measurement appeared in the 80's (KUNKLE; NICKLIN; SULLIVANTAMBOE, 2004).

The objective of this work is to compare if there is a difference between the mercury thermometer and the infrared thermometer and the digital thermometer, in the verification of the body temperature of horses, as well as to identify if there is a difference between the measurement places with the infrared thermometer and the thermometer column of mercury and digital thermometer, having as standard the mercury thermometer.

\section{MATERIALS AND METHODS}

Approved by the Ethics Committee on the Use of Animals (CEUA) with protocol 012/2018 of the Federal University of Pampa.

Seventy two animals were used, aged between four and sixteen years old, of different breeds, weighing between 300$500 \mathrm{~kg}$. The animals were weighed and clinically evaluated to rule out any systemic changes, checking vital parameters such as heart rate, respiratory rate, time of capillary filling and body temperature.

The horses were placed in stalls where they remained for 30 minutes, since immediately before the beginning of the body temperature measurements, the ambient temperature was measured using an infrared thermometer (G-TECH).
Three types of thermometer were used to measure body temperature, the first being infrared $\left(\mathrm{G}-\mathrm{TECH}^{\circ}\right)$, evaluated in three different locations, the buccal mucosa (Figure 1A), the pinna (Figure 1B) and the anal (male) or vaginal mucosa (females) (Figure 1C), the second was the digital thermometer $\left(\right.$ Tech line ${ }^{\circ}$ ) and the third the mercury thermometer, which was used as a standard and compared with the others.

The measurement was carried out with the infrared thermometer, following the order: oral mucosa (on the gum above the upper incisor teeth), pinna and anal (male) and vaginal (female) mucosa. As recommended by the manufacturer, a distance of less than five centimeters was respected between the mucosa surface and the infrared thermometer, with no contact between them. The exposure time to the infrared thermometer was considered, for each evaluation, of five seconds. Then, the measurement was performed with the digital thermometer and mercury thermometer, both measured in the rectal ampoule, respecting the two-minute interval between each assessment. To place the thermometers in the rectal ampoule, both were previously cleaned between animals and lubricated with solid petroleum jelly at room temperature.

The data were submitted to ANOVA analysis of variance and compared by test $\mathrm{T}(5 \%)$. The infrared thermometers (measured in different locations) and the digital were compared to the mercury thermometer that was used as a standard (control), as well as the different measurement locations of the infrared thermometer.

\section{RESULTS}

It was observed that there was no difference between the temperatures obtained with the mercury thermometer and the infrared

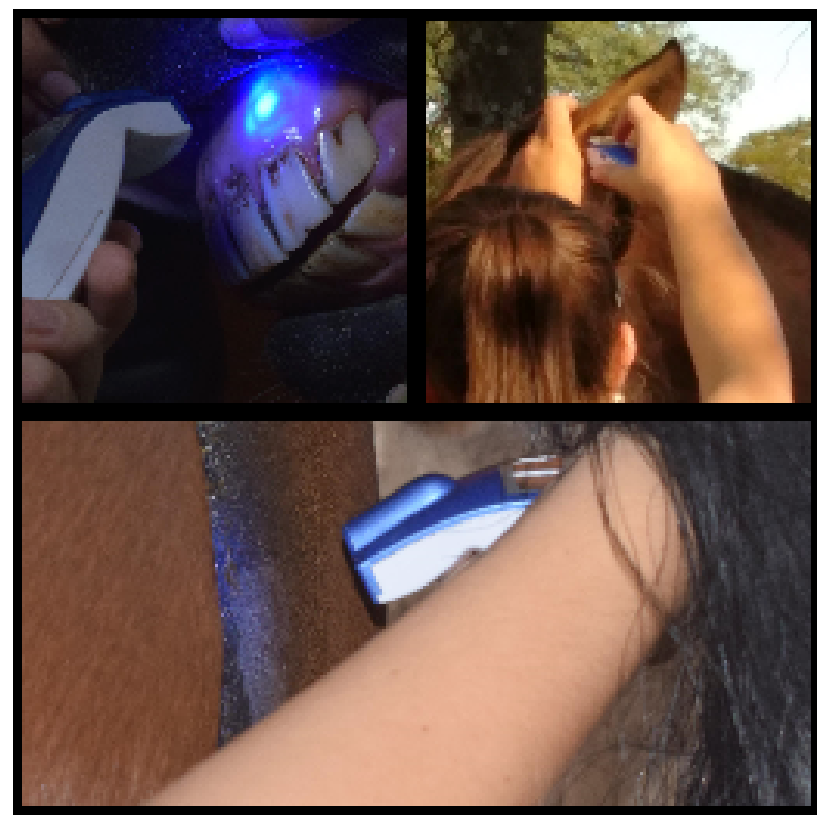

A. Oral mucosa. B. Ear pin. C. Vaginal mucosa (female).

Figure 1. Equine temperature measurement using an infrared thermometer $\left(\mathrm{G}-\mathrm{TECH}^{\circledR}\right)$ at three different measurement points. 
measured in the ear $(\mathrm{P}=0.089)$, neither with the mercury thermometer and the digital thermometer $(\mathrm{P}=0.168)$. The comparison of the temperatures measured between the mercury thermometer and the infrared thermometer on the anal or vaginal mucosa $(\mathrm{P}=0.025)$ and oral mucosa $(\mathrm{P}=0.005)$ showed a difference. The temperature averages obtained with the different thermometers, in different measurement locations are shown in Figure 2.

\section{DISCUSSION}

In this work, the infrared thermometer used in the ear pinna of horses, when compared with the transrectal mercury thermometer, did not show any difference, being an alternative for measuring the temperature of horses. However, the literature presents conflicting results for the equine species, as well as for other species. According to Carter; Dimitrova; Hall (2019) the infrared thermometer used in the ear, was not reliable for monitoring the temperature when correlated with the transrectal mercury thermometer. In cats a study with different types of infrared thermometers measured in the ear, perineum and gums compared with a rectal thermometer was not reliable to measure body temperature (NUTT; LEVY; TUCKE, 2016). According to Schwartz; Juscele; Gimenes (2013), in dogs, the infrared thermometer for measuring mucosa showed greater variability, although it could be used for measurement. In another study with dogs and cats, it was observed that the infrared thermometer when used in the ear is reliable when compared to the traditional technique of transrectal temperature measurement (REXROAT; BENISH; FRADEN, 1999).

In ruminants, studies have shown that the digital thermometer has lower values than the mercury thermometer
(REIS et al., 2010), but in our study this difference was not verified. There are some difficulties regarding the use of the mercury thermometer and the digital one, with animal discomfort being the main one. As the measurement is performed in the anal orifice, this can cause discomfort in animals of blood temperament and thus put the handler at risk. The disadvantage of the mercury thermometer in relation to the digital one is in the fact that the digital thermometer is faster, thus decreasing the chances of an accident. Although these aspects are mentioned, in our study these two thermometers did not differ in terms of discomfort reactions, being considered reliable for measurement.

Studies with horses, cattle, sheep and goats comparing the rectal veterinary mercury thermometer with the rectal (male) and vaginal (female) infrared thermometer were different (POURJAFAR et al., 2010), corroborating the present work in which the infrared thermometer when measured on the anal or vaginal mucosa (females) it was different from the mercury thermometer. A possible explanation for this is the fact that in our work the thermometers used are not specifically for veterinary use.

Studies by Cugmas et al. (2020), demonstrated that the calibrated thermometer comparing different locations on the body had sensitivity to detect hyperthermia in the gums. In our study, the oral mucosa when compared to the evaluation with the mercury thermometer showed a statistical difference, and it is not a suitable place for measuring the temperature in horses. According to Ramey; Bachmann; Lee (2011), the temperature of the gingival mucosa can vary when the lips are opened and this structure is placed in contact with the environment, in that same study it was also

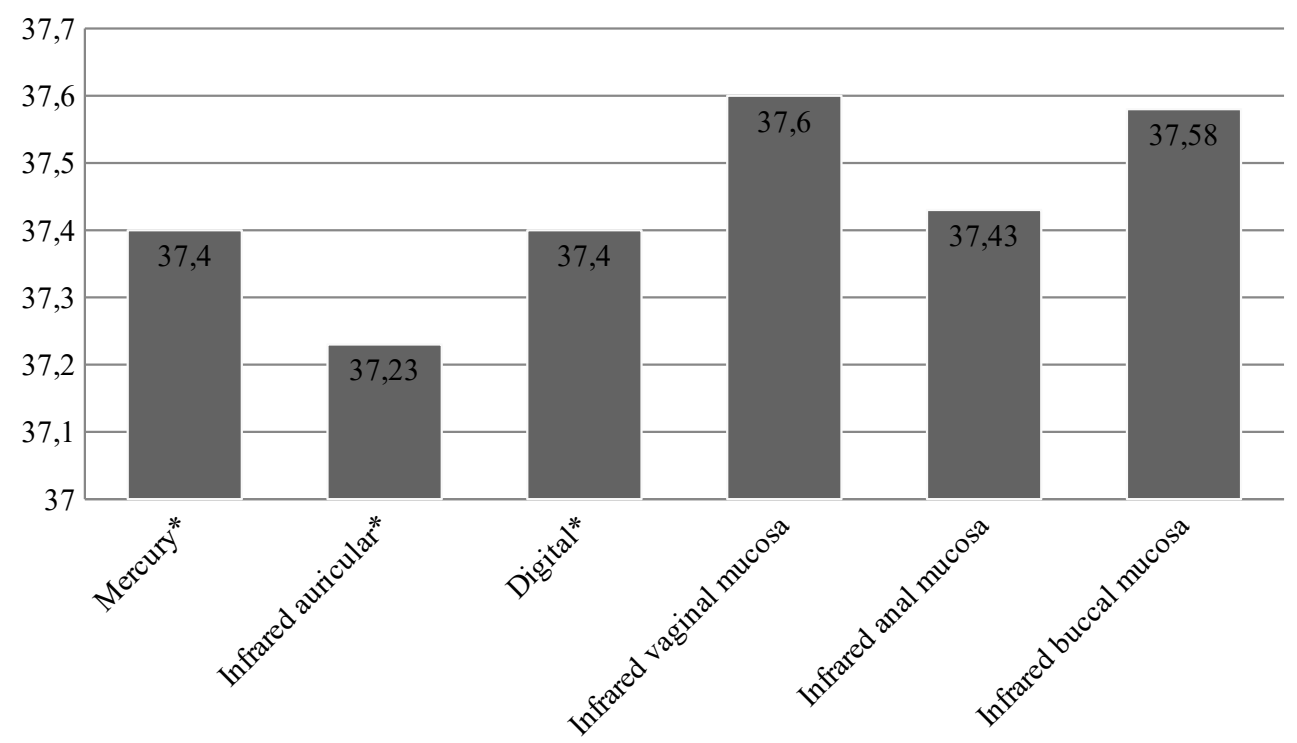

*They showed no difference between them.

Figure 2. Average temperatures $\left({ }^{\circ} \mathrm{C}\right)$ obtained with different thermometers, measured at different locations. 
observed that the closer the temperature was to the teeth, the lower it became.

The measurement of body temperature with the infrared thermometer proved to be easy to perform and with good tolerance, on the part of the animals, in all places, also proving to be a quick alternative. Although gauging in the ear is more tolerable in dogs (SOUSA; CARARETO; PEREIRAJUNIOR, 2011), it has shown viability for the equine species. In our study, we observed some limitations in measuring the temperature in the ear, such as the temperament of some animals, as it causes discomfort when accommodating the thermometer inside the ear, as well as the noise it emits when finished measuring can frighten some animals, with the main reactions being observed abrupt head movements, standing ears and staking. There is also a small difficulty in inserting the equipment in the hairless region in the ear, as recommended by the manufacturer. Despite these disadvantages, the infrared thermometer can be measured in the ear pinna of horses.

A study with babies showed that the infrared thermometer measured on the forehead compared to the contact thermometer measured on the armpit was clinically acceptable. This same study mentions some advantages of the non-contact infrared thermometer when compared to the contact thermometer, one of which is hygiene, since the contact thermometer can lead to contamination from one individual to another. Another advantage presented is the shorter time to obtain the result, where the non-contact infrared thermometer is measured in seconds (SUGAWARA; IMATAKA; YOSHIHARA, 2020). In our study with horses, the advantage of obtaining the fastest result with the infrared thermometer $\left(\mathrm{G}-\mathrm{TECH}^{\circledR}\right)$ was also observed, when compared with the mercury and digital thermometers (Tech line ${ }^{\circledR}$ ), since the measurement with these thermometers take one to two minutes to obtain the result, whereas the infrared thermometer takes just two seconds to obtain the temperature.

The digital thermometer has the advantage of being faster than the mercury thermometer, but it can be considered more invasive when compared to the infrared thermometer. The infrared thermometer measured in the ear proved to be a quick and less invasive option for measuring body temperature in horses. However, there are some limitations in this place, as it is a sensitive and hairy region, which makes it difficult to measure in some animals. Therefore, further studies with veterinary equipment and horses with fever or hypothermia would be needed.

\section{CONCLUSION}

In this work, it was observed that the temperature measurements with the infrared thermometer measured in the auricle and the digital thermometer measured in the anal mucosa are similar to the values obtained with the mercury thermometer measured in the anal mucosa, being therefore options for the measurement of body temperature in equine. However, the infrared thermometer measured on the oral mucosa and on the anal or vaginal mucosa did not prove to be reliable.

\section{THANKS}

Reconquista Agropecuária - For giving up the animals.

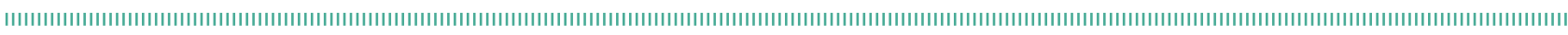
REFERENCES

BRIOSCHI, M. L.; MACEDO, J. F.; MACEDO, R. A. C. Termometria cutânea: novos conceitos. Vasc Br, v. 2, n. 2, p. 151-160, 2003.

CARTER, A. J.; DIMITROVA, A.; HALL, E. J. Field testing two animal-specific non-contact thermometers on healthy horses. Veterinary Nursing Journal, v. 34, n. 4, p. 96-101, 2019.

CUGMAS, B. et al. Comparison between rectal and body surface temperature in dogs by the calibrated infrared thermometer. Veterinary and Animal Science, p. 100120, 2020.

CUNNINGHAM, J.G. Termorregulação. In: Tratado de fisiologia veterinária. $5^{\circ}$ ed. São Paulo: Guanabara Koogan, 1999. p. 507-514.

FEITOSA, F. L. F. Semiologia veterinária: a arte do diagnóstico. 3 ed. São Paulo: Roca, 2014.

FRADEN, J. The development of thermoscan instant thermometer. Clin Pediatr, Suppl, v. 30, n. 4, p. 11-12, 1991.
GREER, R. J. et al. Comparasion of three methods of temperture measurement in hypothermic, euthermic, hyperthermic dogs. Journal of the American Veterinaty Medical Association, v. 230, n. 12, p. 1841-1848, 2007.

KUNKLE, G.; NICKLIN, C.F.; SULLIVAN-TAMBOE D. L. Comparison of body temperature in cats using a veterinary infrared thermometer and a digital rectal thermometer. J Am Anim Hosp Assoc., v. 40, p. 42-46, 2004.

MACKOWIAK, P. Temperature regulation and the pathogenesis of fever. in: Mendel, Douglas and Bennet's principles and pratice of infeccious diseases. $6^{\circ}$ ed. Philadelpha: Elsevier, 2005, v. 2 , p. 703-718.

NUTT, K. R. LEVY, J.K.; TUCKE, S. J. A comparison of noncontact infrared thermometry and rectal thermometry in cats. Journal of Feline Medicine and Surgery, v. 18, n. 10, p. 798-803, 2016. 
POURJAFAR M., et al. Body temperature in horses, cattle, sheep and goats measured by mercury, digital and noncontact infrared thermometers. Online J Vet Res., v. 16, n. 4, p. 195, 2012.

RAMEY, D. ; BACHMANN, K. ; LEE, M. L. A. A comparative study of non-contact infrared and digital rectal thermometer measurements of body temperature in the horse. Journal of Equine Veterinary Science, v. 31, n. 4, p. 191-193, 2011.

REED, S. M; BAYLY, W. M.; SELLON, D. C. Equine Internal Medicine: Fourth Edition. 4. Ed. Elsevier Inc., 2017.

REIS, A. B. et al. Estudo Comparativo Da Temperatura Retal Aferida Por Termômetros Clínicos De Mercúrio E Digital. In: XIX Encontro Anual Iniciação Científica, 2010. Guarapuava. Anais Encontro Anual Iniciação Científica. Guarapuava: UNICENTRO, 2010.
REXROAT, J.; BENISH, K.; FRADEN, J. Clinical Accuracy of VetTempTM Instant Ear Thermometer Comparative Study with Dogs and Cats. p. 1-4, 1999.

SCHWARTZ, D. S.; JUSCELE, F.;GIMENES, A. M. Comparação entre diferentes instrumentos de aferição de temperatura e locais de medição em cães. In: $21^{\circ}$ SIMPÓSIO INTERNACIONALDA INICIAÇÃO CIENTIFICA DA USP, 2013. São Paulo. ANAIS $21^{\circ}$ SIMPÓSIO INTERNACIONAL DA INICIAÇÃO CIENTIFICA DA USP. São Paulo: USP, 2013.

SOUSA M. G.; CARARETO, R.; PEREIRA-JUNIOR, V. A. Comparison between auricular and standard rectal thermometers for the measurement of body temperature in dogs. The Canadian Veterinary Journal, v. 52, n. 4, p. 403-406, 2011.

SUGAWARA, S.; IMATAKA, G.; YOSHIHARA S. Usefulness of NonContact Infrared Thermometer for Early Neonatal Period Using Bland-Altman Analysis. Iranian Journal of Public Health, v. 49, n. 2, p. $411,2020$. 